\title{
Morphologic and Molecular Detection of Dactylogyrus Species in Cyprinus Carpio and Ctenopharyngodon Idella in Southwestern Iran
}

\author{
Mohammad Hossein Razi JALALİ 1 , Sara LARKI ${ }^{* 2}$, Rahim PEYGHAN ${ }^{3}$, Maryam BASTAMI ${ }^{4}$ \\ ${ }^{1}$ Shabid Chamran University of Ahvaz, Professor of Veterinary Parasitology, Center of Excellence of Warm Water Fish Health, Abvaz, Iran \\ ${ }^{2}$ Shabid Chamran University of Abvaz, Assistant Professor of Veterinary Parasitology, Abvaz, Iran \\ ${ }^{3}$ Shahid Chamran University of Abvaz, Professor of Fish Health and Diseases, Center of Excellence of Warm Water Fish Health, Abvaz, Iran \\ ${ }^{4}$ Shabid Chamran University of Abvaz, MSc. Graduate Veterinary Parasitology, Abvaz, Iran
}

\begin{abstract}
Monogeneans gill parasites of the diversified Dactylogyrus genus are host-specific to freshwater fish of the Cyprinidae family. Accurate detection of various Dactylogyrus species is very time-consuming and requires highly experienced personnel; to overcome this problem, the genomic DNA technology has been recently used to detect Dactylogyrus spp. In this study, 23 Cyprinus carpio and 19 Ctenopharyngodon idella isolates were collected from different farms and local markets of Ahvaz, southwest of Iran. The gill arches of each fish were carefully examined under a light microscope. Dactylogyrus species was identified morphologically. Identical species were kept in ethanol for molecular study. Molecular analysis was performed using amplification of the ITS-1 region of the ribosomal RNA gene of the parasite. Then, the amplified PCR products were sequenced. The aligned nucleotide sequences were analyzed to construct the phylogenetic tree of the identified species. The results revealed two lineages including D. extensus isolated from common carp and D. lamellatus taken from grass carp fish. Phylogenetic analysis showed that the detected $D$. extensus and $D$. lamellatus isolates from Khuzestan region were clustered with some Iranian (Guilan), Chinese and Czech isolates. Importing fingerlings from Guilan Province could lead to introducing monogenean infections to native cyprinid fish.
\end{abstract}

Keywords: Dactylogyrus, Common Carp, Grass Carp, Fish, PCR.

\section{İran'ın Güneybatısında Yer Alan Cyprinus Carpio ve Ctenopharyngodon Ídella'daki Dactylogyrus Türlerinin Morfolojik ve Moleküler Tespiti}

ÖZ

Çeşitlendirilmiş Dactylogyrus cinsinin solungaç monojenleri, Cyprinidae ailesinin tatlı su balıklarına ev sahipliğine özgüdür. Çeşitli Dactylogyrus türlerinin doğru tespiti çok zaman alıcı olduğundan ve çok deneyimli personel gerektirdiğinden, genomik DNA teknolojisi son zamanlarda Dactylogyrus spp. Bu çalışmada, Güneybatı İan'ın Ahvaz'ın farklı çiftliklerinden ve yerel pazarlarından 23 Cyprinus carpio ve 19 Ctenopharyngodon idella toplandı. Her balığın solungaç kemerleri, ışı mikroskobu altında dikkatle incelenir. Dactylogyrus türlerinin morfolojik olarak tanımlanması morfolojik olarak belirlenmiştir. benzer türler moleküler çalışma için etanol içinde tutuldu. Moleküler analiz, parazitin ribozomal RNA geninin ITS-1 bölgesinin amplifikasyonu kullanılarak yapıldı. Daha sonra amplifiye PCR ürünleri dizildi. Hizalanmış nükleotit sekansları, tanımlanan türlerin filogenetik ağacını yürütmek için analiz edilir. Sonuçlar, ortak sazandan izole edilen D. extensus ve çim sazan balıklarından alınan D. lamellatus da dahil olmak üzere iki soyun ortaya çıktığını göstermiştir. Filogenetik analiz, Khuzestan bölgesinden tespit edilen D. extensus ve D. lamellatus izolatlarının bazı İran (Guilan), Çin ve Çek Cumhuriyeti izolatlarıyla kümelendiğini gösterdi. Guilan Eyaletinden balıkların ithal edilmesi, yerli Cyprinid balıklarına monojenik enfeksiyonların ortaya çıkmasına neden olabilir.

Anahtar Kelimeler: Sazan, Çim Sazan, Balık, PCR.

To cite this article: Larki S. Jalali M.H.R. Peyghan R. Bastami M. Morphologic and Molecular Detection of Dactylogyrus Species in Cyprinus Carpio and Ctenopharyngodon Idella in Southwestern Iran. Kocatepe Vet J. (2020) 13(3):241-247 


\section{INTRODUCTION}

Various species of cyprinid fish have been imported from the Far East (China), Russia and Eastern European (Romania and Hungary) countries into the fish culture industry of Iran over the past 60 years. The growth rate of this sort of freshwater fish in aquaculture has been on the rise due to the increasing interest of Iranian consumers and the economic and nutritional values of this type of fish (Zolfinejad et al. 2017, Shamsi et al. 2009). When transferring fish to farm ponds and natural habitats, different pathogenic parasites are introduced to native species.

The cyprinid fish naturally harbor various species of monogenean gill parasites. Dactylogyrus Diesing 1850 (Monogenea), is the most common gill parasitic worm of freshwater fish (Woo 2006). This ectoparasite is known to be highly cyprinid fish-specific (Simkova et al. 2007). The host specificity of this species is very high such that each Dactylogyrus species attaches to a distinct niche of the gill arch. Sometimes, this specificity of the host and parasite species is such that they approach phylogenetically close to each other (Simkova et al. 2007, Kadlec et al. 2003). According to the studies by Shamsi et al. (2009) and Daghigh Roohi et al. (2019), each grass carp can carry at least two species of Dactylogyrus on its body surface. Severe parasitism of the gill filaments leads to epithelial hyperplasia followed by serious respiratory failure and negative effects on fish growth. It can also cause a high rate of mortality in small fish (Lu et al. 2012, Tu et al. 2015, Thoney and Hargis 1991). The infected fish are more susceptible to secondary infestation, which increases the intensity of pathogenicity of the Dactylogyrus species, and eventually, the economic loss (Woo et al. 2002, Tu et al. 2015). Dactylogyrus direct life cycle accelerates the rate of parasitic infection distribution, and it can cause disease transmission to reach its epizootic level (Thoney and Hargis 1991). Therefore, early detection of the causative microorganism plays a significant role in controlling and preventing fish infections and economic losses. Also, the taxonomic study of parasites in a specific geographical region helps to find common lineal species, and it informs fisheries organizations of the provinces or countries of where this parasitic infection originates from.

Morphological identification of Dactylogyrus species directly depends on the accurate observation of copulatory components with different shapes and sizes in various species. Since Dactylogyrus is a very small (usually less than $1 \mathrm{~mm}$ ) parasite, it is difficult to differentiate various species, especially when flatted marginal hooks occur in viscous gill media during the mounting process (Sharma et al. 2011). Also, the exact identification of closely resembling species of Dactylogyrus based on morphological characteristics is extremely time-consuming and requires highly experienced personnel. The genomic DNA technology has recently been used for the accurate detection of various microorganism species such as Dactylogyrus.

Previous molecular studies have shown that the ribosomal DNA (rDNA) of Platyhelminthes is a highly conserved region and can be used as a suitable marker for the identification and evolution study of different species (Olson et al. 2003). Most molecular studies have been carried out on the $28 \mathrm{~S}$ rDNA region in cyprinid fish in Iran (Ahmadi et al. 2017, Mozhdeganlou et al. 2011, Daghigh Roohi et al. 2019), while there are limited studies on the internal transcribed spacer 1 (ITS-1) region of $\mathrm{rDNA}$. In the present study, we evaluated the genomic sequence of the internal transcribed spacer 1 (ITS-1) region to detect closely-related Dactylogyrus species in Khuzestan Province, Iran.

\section{MATERIAL and METHODS}

\section{Parasite collection}

A total of 42 freshwater cultured common and grass carp, including 23 C. carpio and 19 C. idella, were acquired as dead but fresh from different aquacultures and local markets of Ahvaz, southwest of Iran. After transferring the fish to the parasitology laboratory of the Faculty of Veterinary Medicine of Shahid Chamran University of Ahvaz, the gill arches of each fish were placed on a plate and examined under stereomicroscope. Then, the identified Dactylogyrus species were separated and collected by the routine methods. Fish sampling continued until 10 Dactylogyrus-infected fish from each species were collected (of the 42 fish, 20 infected fish were found and investigated).

Identification of each parasite was performed based on a survey of the structures of sclerotic attachment and reproductive organs according to Gusev (Gusev 1985). The parasites were observed on clear slides in glycerin using a light microscope equipped with digital image analysis (Carl Zeiss Axiovision LE 4.5). Some similar species were placed in $70 \%$ ethanol before DNA extraction.

\section{Molecular studies \\ DNA extraction and PCR amplification}

Each ethanolic specimen was washed in distilled water to remove alcohol from its tissues. The genomic DNA was extracted using the CinnaPure TMDNA kit (CinnaGen Co., Iran) according to the manufacturer's instructions. The ITS- 1 region of ribosomal RNA genes was amplified with forward (5 -CTGCGGAAGGATCATTATC-3') and reverse (5`-GATCCACCACT'TGCAGTTGT-3`) primers (Mozhdeganlou et al. 2011). Polymerase chain reaction (PCR) was carried out in a thermocycler (A\&E, England) for 38 cycles as follows: $5 \mathrm{~min}$ at 
$94^{\circ} \mathrm{C}$ (initial denaturation) followed by $45 \mathrm{~s}$ at $94^{\circ} \mathrm{C}$ for further denaturation, annealing for $45 \mathrm{~s}$ at $56^{\circ} \mathrm{C}$, $45 \mathrm{~s}$ at $72^{\circ} \mathrm{C}$ and a final extension of $72^{\circ} \mathrm{C}$ for $10 \mathrm{~min}$. The PCR products were investigated on $1.5 \%$ agarose-Tris-acetate-EDTA (TAE) gel, visualized with safe stain under a UV illuminator. Distilled water was used instead of genomic DNA of PCR as negative control.

\section{DNA sequencing}

For morphologic confirmation, the amplified PCR products were purified and sequenced at BioneerKorea Co. using both sets of primers. After reading the sequences, the data were analyzed using BioEdit V. 7.0.5.3 software and the Basic Local Alignment Search Tool (BLAST) programs and databases of the NCBI National Center for Biotechnology Information, BLAST: http://blast.ncbi.nlm.nih.gov/Blast.cgi). The alignment sequences were analyzed by the Molecular Evolutionary Genetics Analysis (MEGA) software, version 10, using default parameters to construct the phylogenetic tree of the isolated species.

\section{Phylogenetic analysis}

The evolutionary history was inferred by using the maximum likelihood estimation method and Kimura 2-parameter model (Kimura 1980). The tree with the highest log likelihood (-2522.07) has been evaluated. The percentage of trees in which the associated taxa clustered together is shown next to the branches. The initial tree(s) for the heuristic search was obtained automatically by applying Neighbor-Join and BioNJ algorithms to a matrix of pairwise distances estimated using the maximum composite likelihood (MCL) approach, and then the topology with superior log likelihood value was selected. A discrete gamma distribution was used to model evolutionary rate differences among sites ( 5 categories $[+G$, parameter $=1.6401])$. The rate variation model allowed for some sites to be evolutionarily invariable $([+\mathrm{I}], 0.00 \%$ sites). The tree is drawn to scale, with branch lengths measured in the number of substitutions per site. This analysis involved 23 nucleotide sequences. There were 227 positions in the final dataset. Evolutionary analyses were conducted in MEGA X (Kumar et al. 2018).

\section{RESULTS}

Twenty Dactylogyrus parasites were isolated from 42 collected fish (19 grass carp and 23 common carp). Microscopic identification of the species revealed that two species of Dactylogyrus including D. extensus (Figure 1) and D. lamellatus (Figure 2) were isolated from the gills of common and grass carp, respectively. The PCR products with the bond lengths of 515 and 618 base pairs were visible on the gel-electrophoresis in C. carpio and C. idella samples, respectively (Figure 3).

The nucleotide sequence of the PCR products was aligned and compared with other registered Dactylogyrus species in the GenBank. According to the phylogenetic analysis, the detected isolates belonged to two distinct clusters. The Khuzestan isolate of $D$. extensus was 95\% homologous with the Chinese (KM277459.1) and Czech (AJ564129) isolates of this species. The Khuzestan isolate of D. lamellatus was also 99\% homologous with the Chinese (KX369221 and KX369218), Czech (AJ564141.1) and Guilan, Iran (MG907490.1) isolates of this species in the GenBank. The results of phylogenetic analysis on the ITS-1 region of rDNA showed that D. extensus (Khuzestan isolate) was grouped together with the same species isolates collected from China and Czech Republic, along with the closely related sister species, D. minutus isolate from Guilan, north of Iran. Also, $D$. lamellatus isolated from Khuzestan Province was clustered with the Iranian isolate (Guilan Province, north of Iran) and the same species isolates collected from China and Czech Republic with high bootstrap $(99 \%)$ (Figure 4).

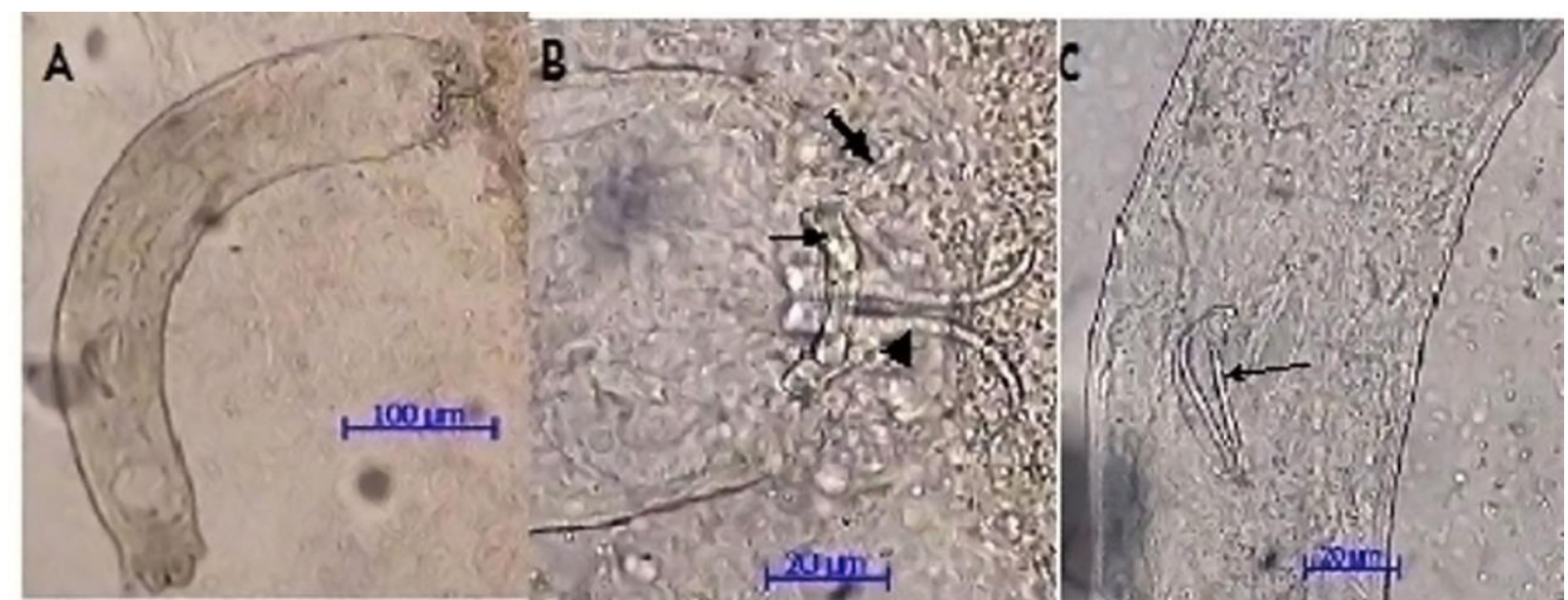

Figure 1. Photomicrograph of Dactylogyrus extensus: A: Adult whole mount worm, B: Haptor of D. extensus; Anchors (arrow head), Dorsal bar (narrow arrow), marginal hook (thick arrow), C: male copulatory organ (arrow). 


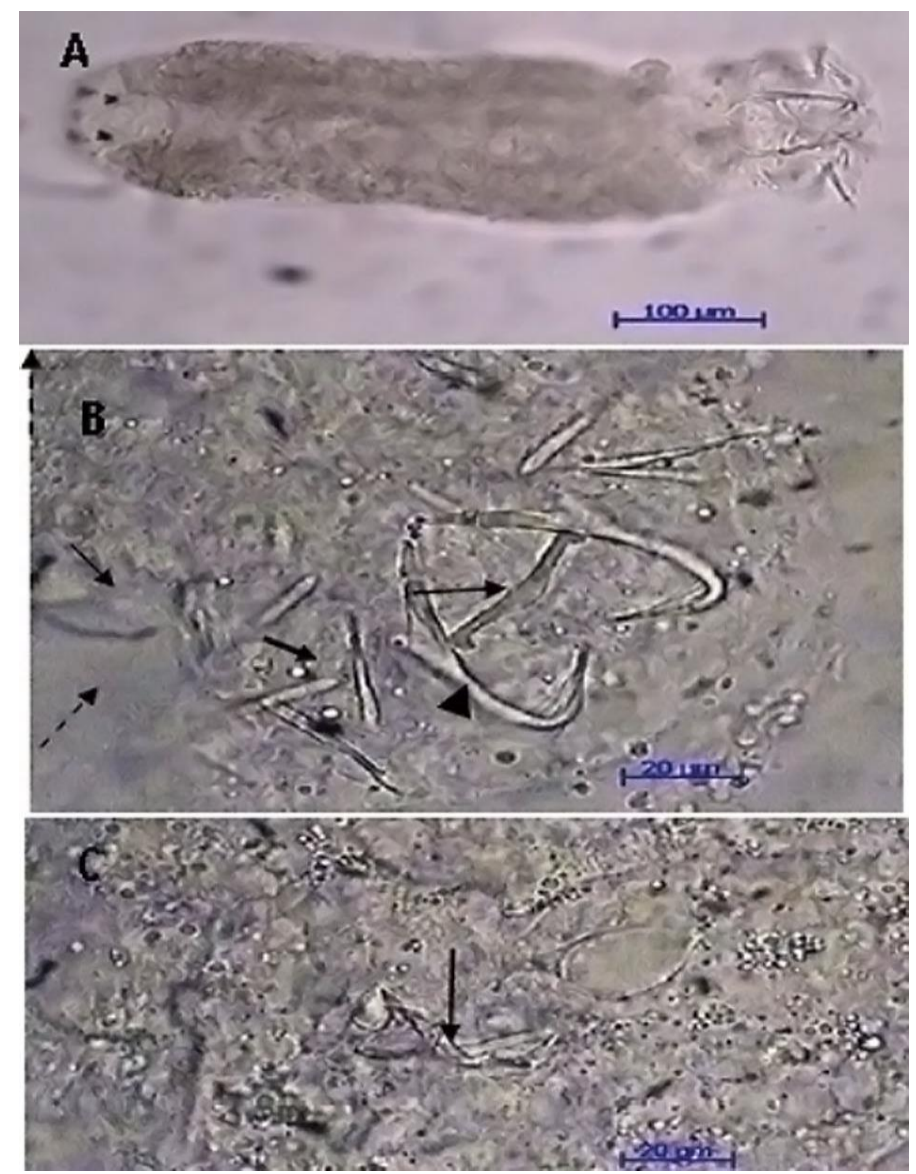

Figure 2. Photomicrograph of Dactylogyrus lamellatus: A: Adult whole mount worm, B: Haptor of D. lamellatus; Anchors (arrow head), Dorsal bar (narrow arrow), marginal hook (thick arrow), C: male copulatory organ (arrow).

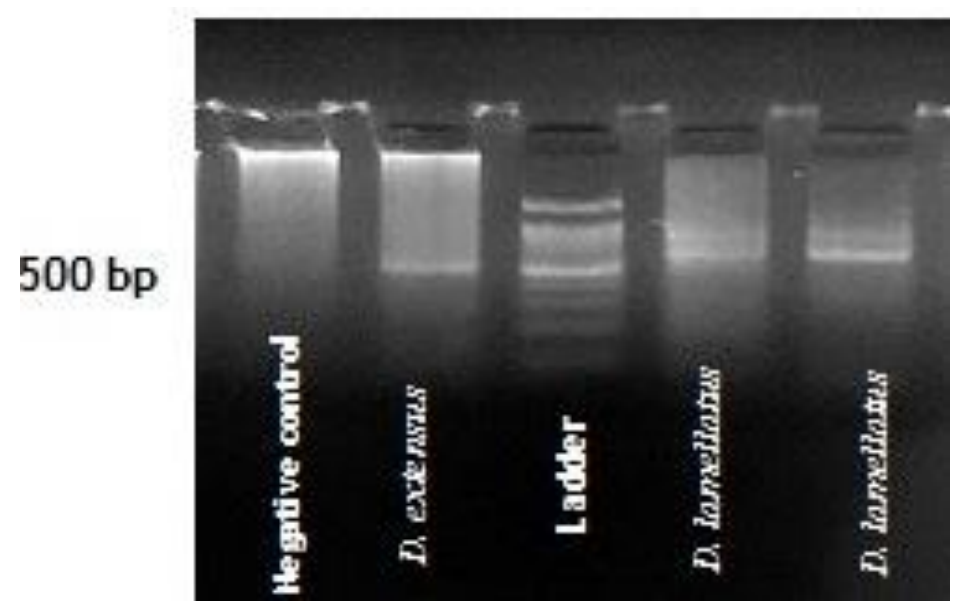

Figure 3. Agarose gel electrophoresis of PCR amplification products from D. extensus and D. lamellatus under UV light. 


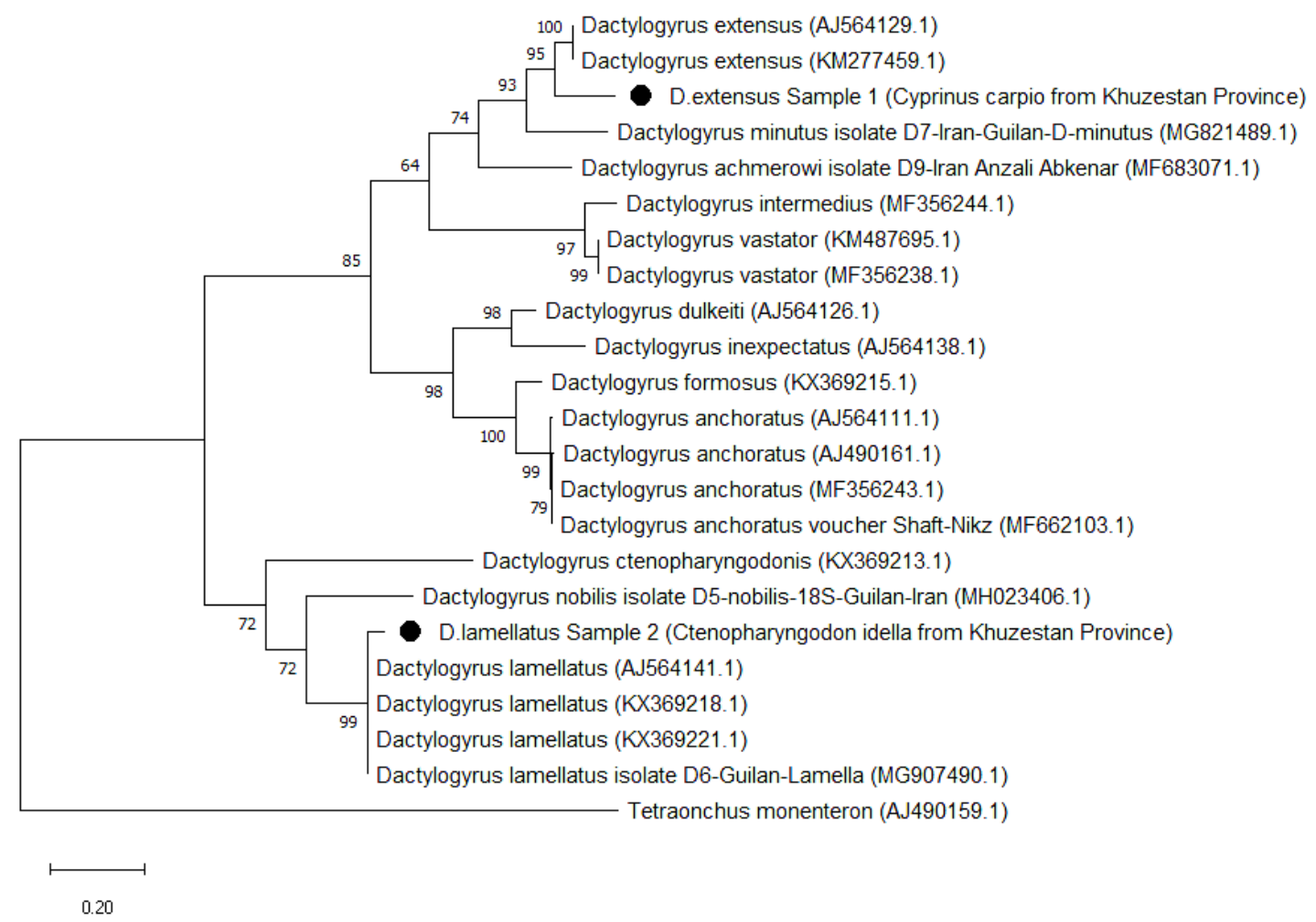

Figure 4. Phylogenetic tree based on the partial sequence of 18S, ITS-1 region and 5.8S rDNA, constructed according to the maximum likelihood method. Black dots represent the Iranian Dactylogyrus isolates (Khuzestan province). Numerals above the branches indicate bootstrap values (\%) from 1000 replicates. The scale bar indicates the proportion of sites changing along each branch.

\section{DISCUSSION}

The routine identification of Dactylogyrus species was performed based on morphological characteristics during the process of appropriate preservation, fixation and staining of genital organs of the parasite (Strona et al. 2009). For this purpose, highly experienced personnel and powerful microscopic instruments are often required due to the minute size of parasites. Thus, the identification of Dactylogyrus species is difficult and time-consuming. Today, molecular techniques using genomic DNA of parasites are used as a more accurate and reliable method, which has significantly aided with the detection of these parasites. In the freshwater fish of Iran, more than 70 species of Dactylogyrus have been identified (Mozhdeganlou et al. 2011), which are mainly specific to cyprinid fish. These parasites have been introduced to the Iranian aquaculture and farming systems during the import of the cyprinid fish from the Far East (China), Russia and Eastern Europe (Romania and Hungary) over the past 40 years (Shamsi et al. 2009).

Shamsi et al. (2009) studied the geographical distribution of Dactylogyrus species in cyprinid fish of different fauna of Iran. They could isolate the species of $D$. anchoratus, D. extensus and D. vastator from Barbus sharpeyi, Carassius auratus gibelio and C. carpio, respectively, in Khuzestan region (Mesopotamian fauna). Therefore, the present study is the first report of the presence of D. extensus in common carp and D. lamellatus in grass carp fish of Khuzestan Province, Southwestern Iran. Borji et al. (2012) detected the species of $D$. extensus and $D$. anchoratus in C. carpio (Borji et al. 2012) under a light microscope from the ponds around Mashhad, Northeastern Iran. Also, in another study in Northeastern Iran, the species of $D$. anchoratus from C. carpio and C. idella, D. extensus from C. carpio and D. lamellatus from C. idella were detected using molecular analysis (Ahmadi et al. 2017). The identified species in Northeastern Iran were similar to Khuzestan species, but since the molecular study was performed on the $28 \mathrm{~S}$ rDNA region, it has not been considered for comparison with Khuzestan isolates in the GenBank. In the north of Iran (Guilan Province), the $D$. lamellatus species was reported in $95 \%$ of the farmed grass carp using molecular methods (Daghigh Roohi et al. 2019). The molecular study of Dactylogyrus species in Guilan Province was the only study from Iran on the ITS-1 region of rDNA. As the freshwater fish of farming systems and local markets in Khuzestan Province are provided by internal and external imports from Guilan Province and other 
countries, monogenean infections are also introduced to native cyprinid fish of the southwest of Iran.

Molnar found that the evolution and maturation time of the D. lamellatus parasites increase with rising water temperature (Molnar 1971). Khuzestan Province is located in southwest of Iran at $29^{\circ} 57^{\prime}-33^{\circ} 0$ ' $\mathrm{N}$ and $47^{\circ} 38^{\prime}-50^{\circ} 32^{\prime} \mathrm{E}$ and this area has a hot desert climate. In the present study, the maximum and minimum temperatures of the Province during the fish sampling period (December 2017 to March 2018) varied from 13 to $31^{\circ} \mathrm{C}$ on different days of months. Therefore, to provide an appropriate habitat for $D$. lamellatus in the intensive farming system, the proliferation of the parasite and the rate of fish involvement should increase. Among Dactylogyrus species, D. extensus has the lowest host specificity and broadest host range. Thus, the parasite can be easily transmitted from other species of fish to common carp (Gibson et al. 1996). Also, D. extensus has a high tolerance to a wide range of temperatures (from 1 to $30^{\circ} \mathrm{C}$ ) and salinity (up to $1.3 \%$ ) of water throughout the year (Jalali 1998, Mahdipour et al. 2004, Jalali and Barzegar 2005). Therefore, the incidence of D. extensus infection in these favorable environmental conditions for the parasite habitat is acceptable.

The phylogenetic analysis showed that the D. extensus and D. lamellatus isolates detected from Khuzestan region had a close affinity with some Iranian (Guilan), Chinese and Czech isolates. Since Khuzestan fish farmers usually provide the need of their cyprinid fish from East (China), Russia and Eastern Europe (i.e., Romania and Hungary) as fry or fingerlings, the Dactylogyrus species can be easily introduced to Iranian water resources and native fish of southwest of Iran. The biodiversity of the detected Dactylogyrus species might be caused by the host specific features and high diversity of these monogenean parasites in various geographical and environmental conditions.

\section{CONCLUSIONS}

This was the first study to demonstrate the occurrence of $D$. extensus and D. lamellatus in common and grass carp from Khuzestan Province, Southwestern Iran. Also, we found that PCR is a reliable and feasible diagnostic tool for the detection of Dactylogyrus species, and it can be applied for largescale assessments in screening programs of customs and fisheries organization to ensure the health of imported aquatic species. Further molecular investigations are needed for the diagnosis and prevention of Dactylogyrus infections in other freshwater fish.

\section{ACKNOWLEDGMENT}

This survey was conducted in the form of a master thesis and supported by a grant from the Shahid Chamran University of Abvar.

The authors would like to express their gratitude to the Research Council of Shabid Chamran University of Ahvaz for their financial support.

Conflict of Interest: The authors declare that they have no conflict of interest.

\section{REFERENCES}

Ahmadi A, Borji H, Naghibi A, Nasiri MR, Sharifiyazdi H. Morphologic and molecular (28S rDNA) characterization of Dactylogyrus spp. in Cyprinus carpio and Ctenopharyngodon idella in Mashhad, Iran. Can J Vet Res. 2017; 81(4): 280 284.

Borji H, Naghibi A, Nasiri M, Ahmadi A. Identification of Dactylogyrus spp. and other parasites of common carp in northeast of Iran. JOPD. 2012; 36: 234-238.

Daghigh Roohi JD, Dalimi A, Pourkazemi M, Ghasemi M. Morphometric and molecular characterization of Dactylogyrus lamellatus isolated from farmed grass carp, Ctenopharyngodon idella (Valenciennes, 1844), in Guilan province, Iran. Iran J Fish Sci. 2019; 1-11.

Gibson DI, Timofeeva TA, Gerasev PI. A catalogue of the nominal species of the monogenean genus Dactylogyrus Diesing, 1850 and their host genera. Syst Parasitol. 1996; 35: 3-48.

Gusev AV. Class Monogenea, In: Keys to Parasites of the Freshwater Fish Fauna of the USSR. (Vol. 2: Parasitic Metazoa), Ed; Bauer ON, Nauka, Leningrad. 1985; pp. 15-251. [in Russian]

Jalali, B. Parasites and parasitic diseases of freshwater fishes of Iran, 1st Ed, Aquaculture Deputy, Fisheries Company, Iran. 1998; p. 564. [In Persian].

Jalali B, Barzegar M. Dactylogyrus spp. (Monogenea: Dactylogyridae) in common carp (Cyprinus carpio L, 1750) of fresh water fishes of Iran and description of the pathogenicity of D.sabuensis Ling, 1985. J Agr Sci Tech. 2005; 7: 9-16.

Kadlec D, Simkova A, Gelnar M. The microhabitat distribution of two Dactylogyrus species parasitizing the gills of the barbel, Barbus barbus. J Helminthol. 2003; 77(4): 317-325.

Kimura M. A simple method for estimating evolutionary rate of base substitutions through comparative studies of nucleotide sequences. J Mol Evol. 1980; 16 (2): 111-120.

Kumar S, Stecher G, Li M, Knyaz C, Tamura K. MEGA X: Molecular Evolutionary Genetics Analysis across computing platforms. Mol Biol Evol. 2018; 35: 1547 1549 .

Lu C, Zhang HY, Ji J, Wang GX. In vivo anthelmintic activity of Dryopteris crassirbizoma, Kochia scoparia, and Polygala tenuifolia against Dactylogyrus intermedius (Monogenea) in goldfish (Carassius auratus). Parasitol Res. 2012; 110(3): 1085-1090.

Mahdipour M, Barzegar M, Jalali B. A survey on monogenean parasites of gills of fishes in Zayandeh-Rud river. Iran J Vet Sci. 2004; 1: 19-28. [In Persian]. 
Molnar K. Studies on gill parasitosis of the grass carp (Ctenopharyngodon idella) caused by Dactylogyrus lamellatus Achmerow, 1952. I. Morphology and biology of Dactylogyrus lamellatus. Acta Vet Acad Sci Hung. 1971; 21(2): 267-289.

Mozhdeganlou Z, Ebrahimzadeh Mousavi H, Shayan P, Soltani M, Ebrahimzadeh E, Rostami M. Detection of single Dactylogyrus spp. in DNA extracted from infected gill tissue of fishes using Polymerase Chain Reaction. Int J Vet Res. 2011; 5(2): 77-80.

Olson PD, Cribb TH, Tkach VV, Bray RA, Littlewood DTJ. Phylogeny and classification of the Digenea (Platyhelminthes: Trematoda). Int J Parasitol. 2003; 33: $733-755$.

Shamsi S, Jalali B, Aghazadeh Meshgi M. Infection with Dactylogyrus spp. among introduced cyprinid fishes and their geographical distribution in Iran. J Vet Res. 2009; 10: $70-74$

Sharma P, Agarwal N, Kumar S. Ribosomal DNA and morphological analysis of Dactylogyrus species from freshwater fishes of India. J Parasitic Dis. 2011; 35(2): 210-214.

Simkova A, Pecinkova M, Rehulkova E, Vyskocilova M. Dactylogyrus species parasitizing European Barbus species: morphometric and molecular variability. Parasitology. 2007; 134(12): 1751-1765.

Strona G, Stefani F, Galli P. Field preservation of monogenean parasites for molecular and morphological analyses. Parasitol Int. 2009; 58: 51-54.

Thoney DA, Hargis WJ. Monogenea (platyhelminthes) as hazards for fish in confinement. Annu Rev Fish Dis. 1991; 1: 133-153.

Tu X, Ling F, Huang A, Wang G. The first report of Dactylogyrus formosus Kulwiec, 1927 (Monogenea: Dactylogyridae) from goldfish (Carassius auratus) in central China. Parasitol Res. 2015; 114(7): 2689-96.

Woo P, Bruno D, Lim L. Diseases and disorders of finfish in cage culture, CABI, Wallingford, Oxfordshire. 2002; p. 353.

Woo PTK. Fish diseases and disorders. Vol. 1, protozoan and metazoan infections, 2nd Ed, CABI, Wallingford, Oxfordshire. 2006; p. 791.

Zolfinejad K, Khara H, Filizadeh Y. Food preference and growth of grass carp, Ctenopharyngodon idella (Cuvier and Valenciennes, 1844) fed some aquatic and terrestrial plants. Iran J Fish Sci. 2017; 16(4): 1278-1286. 